\title{
The Influence of Telenursingagainst Adherence to Anti TB Treatment toward Tuberculosis Patient in BIMA City
}

\author{
Julhana $^{1}$, Awan Dramawan ${ }^{1}$, A. Haris ${ }^{1}$, Syaiful ${ }^{1}$ \\ ${ }^{1}$ Mater of Science Nursing, Nursing Department of Mataram Health Polytechnic (PoltekkesMataram), \\ Bima 84112, West Nusa Tenggara-Indonesia
}

\begin{abstract}
Tuberculosis (TB) is an infectious disease that is caused by Mycobacterium tuberculosis, which attacks various organs, especially lungs. This disease must be treated immediately before it causes complications even death. The number of TB cases in Indonesia was 420,994 cases in 2017. Lack of adherence against TB treatment still becomes an obstacle of global health, and mobile phone-based interventions have potential to solve this problem. Furthermore, this research aimed at investigating the influence of telenursing against adherence to anti-TB treatment toward patient with tuberculosis. This research was conducted in Bima City, West Nusa Tenggara Province, Indonesia which consisted of 3 (three) Public Health Centers. Method of this research was experimental anddesign in this research used quasi experimental design (One group PretestPosttest Design). Moreover, results of this research showed that TB respondents before being treatedby telenursing who were in category of moderate adherence were 14 respondents $(23.3 \%)$, meanwhile, in category of poor adherence were 46 respondents (76.7\%). After being treatedby telenursing, TB respondents who were in category of high adherence were 60 respondents $(100 \%)$. Test through SPSS was obtained a significant result which was 0.001 for intervention with a significance level of 0.05 . Because $p$ value was $<0.05$, then Ho was rejected, which meant that there was a significant difference in results between before and after being treated by telenursing.
\end{abstract}

Keywords: Tuberculosis, Telenursing, Adherence to Treatment.

\section{Introduction}

Tuberculosis (TB) is an infectious disease that is caused by Mycobacterium tuberculosis, which attacks various organs, especially lungs. This disease must be treated immediately before it causes complications even death. WHO reported that in 2012, there were 1.1 million patients $(13 \%)$ of whom were HIV positive patients and the patients increased in 2013 as many as 8.6 million TB cases. Moreover, there were $75 \%$ of these patients in African region.

\section{Corresponding Author:}

\section{Julhana}

Mataram Health Polytechnic (PoltekkesMataram), Nursing Department, Jl. Soekarno Hatta 03- 84112, Bima-West Nusa Tenggara-Indonesia e-mail: julhana27@gmail.com

Mob.: +6282112020233
In 2017, the number of TB cases in Indonesia was 420,994 cases (data as of 17 May 2018). However, based on sex variable, male is 1.4 times greater than the female one. Results of tuberculosis prevalence survey showed that males were three times higher than females. This occurs because males are more exposed to have risk factors, such as smoking and less medication adherence than the females ${ }^{1}$.

The highest prevalence of $\mathrm{TB}$ based on age in 2013 was at the age of 65-74 years $(0.8 \%)$. According to occupation variable, respondents who did not work were $11.7 \%$. According to the highest education variable, respondents who did not have education from school were $0.5 \%$. Furthermore, the highest prevalence of TB based on province in 2014 was in Papua (302 cases/100,000 population), meanwhile, the lowest one was in Yogyakarta or DIY Province (74/100,000 population), and West Nusa Tenggara Province was in the same position as Central Sulawesi Province which was as much as $136 / 100,000$ population ${ }^{2}$. 
In West Nusa Tenggara Province in 2016, the number of TB patients (all types) was 5,828 patients, and 3,860 of them were new smear positive cases. Whereas in 2017, the total number of TB patients was 6,644 patients and the 4,149 patients of them were new smear positive pulmonary TB cases. When it was compared to 2016, TB cases in 2017 increased to be $14.04 \%^{3}$.

Clinical pulmonary TB cases in Bima City in 2016 were 206 cases and new smear positive pulmonary TB cases in 2016 were found 98 cases. It decreased if it was compared with TB cases in 2015 which 167 cases were reported (Division of Bina P2PL of Public Health Office in Bima City 2017). In 2017, the number of new smear positive pulmonary TB cases was 149 cases and the total number of TB cases was 282 cases. In 2018, patients with smear positive and positive X-rays were obtained as many as 210 patients with data that was collected quarterly, data from first quarter to fourth quarter were 210 patients from all Public Health Centers ${ }^{4}$.

Failure in the treatment based on Basic Health Research 2010 was found that $19.3 \%$ of pulmonary TB patients did not adhere to take medication. Lack of adherence to TB treatment becomes a challenge of global health, and mobile phone-based interventions have the potential to solve this problem ${ }^{5}$. Based on the results of previous research were found that there were pulmonary TB patients who failed to undergo complete and regular treatment. This research used SMS (Short Message Service) as a reminder for adherence and cure of TB treatment but the success rate was $63.5 \%$ in intervention group and $62 \%$ in control group due to dropouts at sixth month of treatment ${ }^{6}$. Meanwhile, conducted research from other researches showed that result of TB medication increased when the health education, psychological intervention, reminder (SMS (Short Message Service)) or mobile digital technology were applied ${ }^{7}$.

One of interventions which are able to be conducted in order to increase adherence of TB treatment is through telenursing. Telenursing is a process of providing nursing care by utilizing technology of communication and information ${ }^{8}$.

Another source states that telenursing is a media of health information technology that is able to be applied in nursing care. Thus, the people are able to access the needs of nursing services through telecommunication media9. Telenursing services are able to provide information about what medicine that must be taken and advice that should be taken or not, making appointments for visits and disease management. Moreover, the role of telenursing is very effective for cost and time aspect, even it is able to improve the quality of nursing services ${ }^{9}$.

People in Bima City, West Nusa Tenggara Province, Indonesia mostly have used communication technology, which is mobile phone. It is a communication tool that is used either directly or indirectly. The example is for Short Message Service (SMS) that is used to send and receive messages in text form from and to the other mobile phones. The text that is sent can consist of words or numbers or even an alphanumeric combination ${ }^{10}$. Communication through mobile phone can be utilized to overcome health problems and one of the health problems is tuberculosis (TB).

\section{Method}

This research method was experimental. Meanwhile, research design here utilized quasi experimental design (One group Pretest-Posttest Design) due to without using control group ${ }^{11}$. This research was conducted in Public Health Centers in Bima City in July - December 2019.

Population in this research for all public health centers in per quarter was 60 patients. Sampling technique in this research was total sampling. Total sampling is a sampling technique which the number of samples is the same as the population ${ }^{12}$.

\section{Data collection in this research was conducted by:}

1. This research was conducted by utilizing SMS (Short Message Service) as time reminder to take medicine which contained an appeal to immediately take medicine. At the beginning of treatment, patient and health workers had coordinated the time to take medicine in the morning, afternoon, or evening, then, the medicine was taken appropriately at the agreed time. This aimed at improving medication adherence and timeliness of sending SMS, thus, it was in order to avoid TB drug resistance to the patients. SMS was sent 10 minutes before taking the medicine once a day for two months at the beginning of treatment, then, the SMS was sent three times in a week for the following month. In order to confirm that the respondent had opened and understood the messages that had been sent, a Short Message Service (SMS) that was sent contained questions which related to time to take the medicine, such 
as "Have you taken the medicine? And the patient answered the message that was sent.

2. Filling Morisky Medication Adherence Scales (MMAS 8) questionnaire sheets. Some experts have provided opinions on how to measure medication adherence, including the measurement of medication adherence, which can be identified in 7 ways, which are: doctor's decision based on examination results, observation against medical treatment schedule, assessment on medical treatment goals, calculation of the number of tablets/pills at the end of medical treatment, measurement of drug levels in blood and urine, interviews with patients and filling the special forms. Based on this theory, researchers collected data through filling special form (questionnaire) which was calculated by using medication adherence score. The questionnaire that was used by the researchers was Morisky Medication Adherence Scales (MMAS 8) questionnaire to the patients who took medical treatment at the public health centers by calculating total score from the questionnaire and classifying into three levels, which were high adherence (score 0), moderate adherence (score 1-2), and poor adherence (score 3-8). The scale that was used was ordinal data scale. Furthermore, MoriskyMedication Adherence Scales (MMAS-8) questionnaire was used as an instrument. Validity and reliability tests had been conducted by several previous researchers and it showed validity and reliability to assess medication adherence.

\section{Result}

Data in this research included respondents' characteristics that consisted of age, sex, latest education, and occupation which were presented in the following table:

\section{Data of Characteristics of Respondents with Pulmonary TB:}

Table 1.1 Distribution of Characteristics of Respondents with Pulmonary TB in Public Health Center in Bima City 2019

\begin{tabular}{|l|c|c|c|}
\hline Variable & N & $\mathbf{\%}$ & P value \\
\hline Age & $45.73 \pm 51.00$ & \\
\hline Mean \pm Median & 18.198 & \\
\hline SD & 81 & \\
\hline Maximun &
\end{tabular}

\begin{tabular}{|c|c|c|c|}
\hline Variable & $\mathbf{N}$ & $\%$ & $P$ value \\
\hline Minimun & \multicolumn{2}{|c|}{12} & \\
\hline $12 / 20-25$ years old & 14 & 23.3 & \\
\hline 25-60/65 years old & 38 & 63.3 & .978 \\
\hline$>65$ years old & 8 & 13.3 & \\
\hline \multicolumn{4}{|l|}{ Sex } \\
\hline Male & 39 & 65.0 & \multirow{2}{*}{.001} \\
\hline Female & 21 & 35.0 & \\
\hline \multicolumn{4}{|l|}{ Latest Education } \\
\hline Elementary School & 15 & 25.0 & \multirow{3}{*}{.255} \\
\hline Junior High School & 32 & 53.3 & \\
\hline Senior High School & 13 & 21.7 & \\
\hline \multicolumn{4}{|l|}{ Occupation } \\
\hline Not Working & 19 & 31.7 & \multirow{2}{*}{.001} \\
\hline Working & 41 & 68.3 & \\
\hline
\end{tabular}

Analysis result of respondents' ages was found that most of respondents who were at the maturity age of 25-60/65 years were 38 respondents $(63.3 \%)$, young adult age of 12/20-25 years oldwere 14 respondents $(23.3 \%)$, and elderly age of $>65$ years were $8(13.3 \%)$ respondents. It was tested by Likelihood Ratio and it was obtained $p$ value $=0.978$, which meant that $p$ value $>$ 0.05 . In other words, there was no significant influence between age and medication adherence. Analysis results of respondents' sex was found that more than half of the respondents were male which were 39 respondents $(65 \%)$. Besides, chi square test was conducted with $\mathrm{p}$ value of 0.001 , which meant that there was a significant correlation between respondents' sex and medication adherence. Meanwhile, analysis results of respondents' latest education was found that most of the respondents had graduated from Junior High School education which were 32 respondents $(53.3 \%), 15$ respondents $(25 \%)$ had graduated from elementary school education, and 13 respondents $(21.7 \%)$ had graduated from senior high school education. Moreover, chi square test was conducted with $p$ value of 0.255 , which meant that there was no significant correlation between education and medication adherence. Analysisresults of respondent's occupation was found that most of the respondents who had occupation were 41 respondents $(68.3 \%)$, meanwhile, 19 respondents $(31.7 \%)$ did not have any occupation. Chi square test was conducted with $\mathrm{p}$ value $=0.001$, which meant that there was a significant correlation between occupation and medication adherence. 
2. Data Analysis: Based on the research results regarding the influence of telenursing against adherence to anti TB treatment at Public Health Center in Bima City, could be described as the following data: a. Frequency Distribution of Adherence on Respondents to Take Anti-TB Medicine Before And After Telenursing Treatment.

Table 1.2: Frequency Distribution of Adherence on Respondents to Take Anti-TB Medicineat Public Health Centers in Bima City 2019

\begin{tabular}{|l|c|c|c|c|}
\hline \multirow{2}{*}{$\begin{array}{l}\text { Respondents with } \\
\text { Pulmonary TB }\end{array}$} & \multicolumn{3}{|c|}{ MMAS of Medication Adherence } & \multirow{2}{*}{ Total } \\
\cline { 2 - 5 } & High Adherence & Moderate Adherence & Poor Adherence & \\
\hline \multirow{2}{*}{ Pre Test } & 0 & 14 & 46 & 60 \\
& 0 & $23,3 \%$ & $76,7 \%$ & $100 \%$ \\
Post Test & 60 & 0 & 0 & 60 \\
& $100 \%$ & 0 & 0 & $100 \%$ \\
\hline
\end{tabular}

P value .001

Based on table 1.2, it showed that respondents with pulmonary TB before being treated by telenursing who were in category of moderate adherence were 14 respondents $(23,3 \%)$, meanwhile, in category of poor adherence were 46 respondents $(76,7 \%)$. Then, all of the respondents were treated by telenursing and the result showed that respondents who were in category of high adherence were 60 respondents $(100 \%)$.

b. Difference in Average of Medication Adherence before and after Telenursing Treatment

Table 1.3: Wilcoxon Test for the Difference of Average Before and After Telenursing Treatment

\begin{tabular}{|l|l|c|c|c|}
\hline & & $\mathbf{N}$ & Mean Rank & Sum of Ranks \\
\hline \multirow{4}{*}{ Post Test - Pre Test } & Negative Ranks & $0^{\mathrm{a}}$ & .00 & .00 \\
\cline { 2 - 5 } & Positive Ranks & $60^{\mathrm{b}}$ & 30.50 & 1830.00 \\
\cline { 2 - 5 } & Ties & $0^{\mathrm{c}}$ & & \\
\cline { 2 - 5 } & Total & 60 & & \\
\hline
\end{tabular}

According to table 1.3, it was obtained that negative ranks of adherence to anti TB treatment between pretest and post-test was 0 , which showed that there was no significant reduction value from pre-test to post-test or the pre-test value was greater. Meanwhile, positive ranks for pre-test and post-test showed that there were 60 positive data $(\mathrm{N})$, which meant that the 60 respondents experienced an increase in adherence to take antiTB treatment from pre-test to post-test. However, the average of the increase was 30.50 , while the number of positive ranks or sum of ranks was 1830.0.

c. The influence of Telenursing against adherence to anti TB treatment on patient with tuberculosis
Table 1.4 Wilcoxon Test Before and After Treatment of Adherence to Anti TB Treatment

\begin{tabular}{|c|c|}
\hline & Post Test-Pre Test \\
\hline$Z$ & $-7.152^{\mathrm{a}}$ \\
\hline P value & .001 \\
\hline
\end{tabular}

This research used Wilcoxon test in order to investigate whether there was a significant difference between two dependent groups or not. Tests with SPSS was obtained significant results of 0.001 for interventions with significance level of 0.05 because $p$ value $<0.05$, Ho was rejected. In other words, there was a significant difference in results between before and after telenursing 
treatment. Based on the results of the test through SPSS, telenursing had a significant influence against the adherence to take anti TB treatment for patients with tuberculosis.

\section{Discussion}

This chapter described discussion of research results that had been conducted at Public Health Center in Bima City, West Nusa Tenggara,Indonesia.

1. Identifying the average of respondents before and after being treated by telenursing against the adherence to take anti-TB treatment for Tuberculosis patients in Bima City: Based on table 1.2, it showed that $\mathrm{TB}$ respondents before being treated by telenursing were in category of moderate adherence, which were 14 respondents $(23.3 \%)$ and in category of poor adherence were 46 respondents $(76.7 \%)$. Then, after all of the TB respondents were treated by telenursing treatment, they were in category of high adherence, which were 60 respondents $(100 \%)$.

Based on the research result that was conducted byBediang, it was obtained that this research used SMS as a reminder for adherence and TB cure ${ }^{13}$. The success rate was $63.5 \%$ in intervention group and $62 \%$ in control group due to a drop out at sixth months of treatment ${ }^{14}$. This was in accordance with the research results that had been conducted by noticing to several things. Thus, in order to achieve success of increasing awareness for TB patients' treatment in this research was through increasing respondents' knowledge and strengthening the role of PMO by taking actions. One of the actions was providing a book of nursing care for tuberculosis patients, being responsive for providing feedback from respondents, and patient absence from taking the treatment package. Furthermore, research results showed that the success rate or respondents who were in category of high adherence after telenursing treatment were 60 respondents $(100 \%)$ and there were no respondents who dropped out in doing treatment in this research.

2. Identifying the influence of telenursing against adherence to anti TB treatment on patient with tuberculosis in Bima City: Tests with SPSS was obtained significant results of 0.001 for interventions with a significance level of 0.05 because $p$ value $<0.05$, then Ho was rejected. In other words, there was a significant difference in results between before and after telenursing treatment. Most of respondentswho did not adhere to treatment were at early elderly age of 46-55 years and they were 17 respondents (28.3\%). 15 respondents $(25 \%)$ were at late adolescence of 17 25 years. 13 respondents were at late elderly of 56-65 years $(21,7 \%)$. This was in line with results of conducted research by Erawatyningsih et al in 2009 which showed that most of respondents who did not adhere to treatment were respondents who were 49-55 years old group rather than other age groups ${ }^{13}$.

When we looked at the age variable, most of respondents in this research were in age group of 55 year more or in other word, it was the late elderly age group or unproductive age. At the elderly age of more than 55 years, a person's immunolosis system decreased. Hence, they were very vulnerable against various diseases, including pulmonary TB disease. The increase of TB cases was influenced by the immune system, nutritional status, personal hygiene, and the density of the residential environment ${ }^{15}$.

Analysis results of respondents' sex in this research was found that more than half of the respondents were males, which were 39 respondents (65\%). This was in line with results of conducted research by Aziz et al which showed that there were $336(91.8 \%)$ male respondents and $30(8.2 \%)$ female respondents and chi square test was conducted with $p$ value of 0.001 . In other words, it meant that there was a significant correlation between sex and medication adherence ${ }^{16}$. The results of Riskesdas (basic health research) in 2013 showed that diagnosis of pulmonary TB based on sex was male $(0.4 \%)$ and female $(0.3 \%)^{17}$. The previous Indonesia health profile in 2012 showed that smear positive pulmonary TB cases in men were almost 1.5 times (59.4\%) greater rather than in women $(40.6 \%)$.

Higher TB case rate in men rather than women could reflect on the exposure on infection risk (including lifestyle, such as smoking, alcohol consumption, and occupation which were from indoor pollutants) and disease progression ${ }^{18}$. This was in accordance with result of conducted research by Haslinda \& Juni, (2017), which showed that smoking, alcohol and drug abuse were risk factors for discontinuation of TB treatment ${ }^{19}$. Another conducted research by (Falletehan, 2014) regarding smokers, who were found almost 18,000 people that represented general population over the past three years, "were found twofold increase of the risk of active TB on smokers rather than those who never smoked", smokers had more potential to suffer tuberculosis (TB ${ }^{20}$. 
Analysis results of respondents' latest education aspect was found that most of the respondents had graduated from senior high school education which were 21 respondents (35\%), 15 respondents (25\%) had graduated from elementary school education, and 11 respondents (18.3\%) had graduated from junior high school education. Chi square test was conducted with $\mathrm{p}$ value of 0.255 , which meant that there was no significant corelation between education and medication adherence. Nevertheless, education is very important to improve someone's knowledge and insight, likewise with health education that can enable a person to improve control and individual health and make changes voluntarily in individual behavior.

This was in line with conducted research by Prayogo, (2013) which stated that low level of education would impact on lack of person's knowledge and insight against TB disease. Thus, it would impact on person's level of medication adherence ${ }^{21}$. Other researches showed that low level of education and inadequate knowledge affected more on the level of medication adherence ${ }^{16}$. Therefore, it was expected that TB patient would improve health education in order to encourage contributions for controlling TB.

Analysis results of respondents' occupation was found that most of respondents had occupation as farmer which were 16 respondents (26.7\%), 13 respondents $(21.7 \%)$ worked as private employees, 10 respondents (16.7\%) worked as laborers. Moreover, chi square test was conducted with $\mathrm{p}$ value of 0.001 , which meant that there was asignificant correlation between occupation and medication adherence. Nevertheless, occupation is an indicator to measure person's education level. Knowledge that is influenced by education level is one of predisposing factors that has a role in influencing person's decision to behave healthily ${ }^{22}$.

According to result of conducted research by (5) showed that mobile phone-based interventions helped to overcome barriers such as stigma, loss of privacy, limited transportation, and to make respondents feel "cared for" and they were "responsible for their own care". Being compared to respondents who were not treated through mobile phone-based interventions, SMS interventions significantly improved adherence to anti TB treatment. However, this was in accordance with the research result that was obtained in this research that there was a significant difference between before and after being treated by telenursing against medication adherence ${ }^{5}$.

\section{Conclusion}

\section{Conclusion of this research as follows:}

1. Description of adherence to anti TB treatment improved all respondents which were 60 respondents (100\%).

2. There was a significant influence and difference against adherence to anti TB treatment after telenursing treatment in pre and post intervention $(p=0.001)$.

Ethical Clearance: Taken from University Mataram.

Source of Funding: Health Polytechnic of Ministry of Health at Mataram.

\section{Conflict of Interest: None}

\section{References}

1. Kementerian Kesehatan RI. Infodatin Pusat Data dan Informasi Tuberkulosis. InfoDATIN [Internet]. 2018; Tersedia pada: file://C:/Users/ACER/ Downloads/InfoDatin-2016-TB(1).pdf

2. Kemenkes RI. Tuberkulosis (Temukan Obat Sampai Sembuh). Pusat Data dan Inforasi Kementerian Kesehatan RI. 2016. hal. 2-10.

3. Dinas Kesehatan. Profil Kesehatan Provinsi Nusa Tenggara Barat Tahun 2017. Provinsi Nusa Tenggara Barat Tahun 2017. 2017;1-85.

4. Kementerian Kesehatan RI Badan Penelitian dan Pengembangan. Hasil Utama Riset Kesehatan Dasar. Kementrian Kesehat Republik Indones [Internet]. 2018;1-100. Tersedia pada: http://www. depkes.go.id/resources/download/info-terkini/ hasil-riskesdas-2018.pdf

5. Qu Y, Pan Y, Yao L, Liu Z, Chen S, Xiang L. Mobile phone based interventions for promoting adherence to tuberculosis treatment: a systematic review and meta-analysis. Vol. 386, The Lancet. 2015. hal. S29.

6. Bediang G, Stoll B, Elia N, Abena JL, Geissbuhler A. SMS reminders to improve adherence and cure of tuberculosis patients in Cameroon (TB-SMS Cameroon): A randomised controlled trial. BMC Public Health. 2018;

7. Nahid P, Falzon D, Jaramillo E, Miller C, Jarlsberg $\mathrm{L}$, Alipanah N, et al. Adherence interventions and outcomes of tuberculosis treatment: A systematic 
review and meta-analysis of trials and observational studies. Vol. 15, PLOS Medicine. 2018. e1002595 hal.

8. Mar'ah Has EM. A Nursing Management Model to Increase Medication Adherence and Nutritional Status of Patients with Pulmonary TB. J NERS. 2015;10(1):189.

9. American Association of Ambulatory Care Nursing. Definitions of telehealth nursing/tele nursing. 2011;

10. Muharyani, Putri W. Aplikasi Short Message Service(Sms) Dalam Promosi Kesehatan Reproduksi Di Komunitas. Universitas Indonesia; 2011.

11. Arikunto S. Prosedur Penelitian Suatu Pendekatan Praktek. Jakarta: Rineka Cipta; 2002.

12. Sugiyono. Metodelogi Penelitian Kuantitatif, Penelitian Kualitatif Dan R \& D. Bandung, Jawa Barat: CV Alfabeta; 2012.

13. Erawatyningsih E, Purwanta, Subekti H. FaktorFaktor yang Mempengaruhi Ketidakpatuhan Berobat pada Penderita Tuberkulosis Paru. Fakt Yang Mempengaruhi Ketidakpatuhan Berobat Pada Penderita Tuberkulosis Paru. 2009;25(3):117-24.

14. Bediang G, Stoll B, Elia N, Abena JL, Nolna D, Chastonay $\mathrm{P}$, et al. SMS reminders to improve the tuberculosis cure rate in developing countries (TB-SMS Cameroon): A protocol of a randomised control study. Trials. 2014;

15. Manalu SP. Manalu SP. FAKTOR-FAKTOR YANG MEMPENGARUHI KEJADIANTB PARU DAN UPAYA PENANGGULANGANNYA Factors Affecting The Occurrence Of Pulmonary $\mathrm{Tb}$ And Efforts To Overcome Helper Sahat $\mathrm{P}$ Manalu*. J Ekol Kesehat. 2010;9:1340-6. J Ekol Kesehat. 2010;9:1340-6.

16. Aziz K, Hisam A, Azam N, Pervaiz F, Mehmood $\mathrm{H}$. KNOWLEDGE OF DISEASE AND ADHERENCE TO ANTI-TUBERCULOSIS TREATMENT-A CROSS SECTIONAL
RESEARCH IN RAWALPINDI DISTRICT. 2019;69:267-73.

17. Badan Penelitian dan Pengembangan Kesehatan. Riset Kesehatan Dasar. 2013;306.

18. Puspasari N. Karakteristik pasien tuberkulosis yang memperoleh pengobatan kategori 2 di UP4 ProvinsiKalimantan Barat tahun 2009. Universitas Tanjungpura; 2014.

19. Haslinda N, Juni MH. Systematic Review of Factors Associated With Medication Adherence Among Pulmonary Tuberculosis Patients. Vol. 4, International Journal of Public Health and Clinical Sciences. 2017. hal. 2289-7577.

20. Falletehan RA. HUBUNGAN PERILAKU MEROKOK DENGAN KEJADIAN TUBERKULOSIS PARU [Internet]. Vol. 2014. Universitas Muhammadiyah Surakarta; 2014. Tersedia pada: https://repositories.lib. utexas.edu/handle/2152/39127\%0Ahttps://cris . brighton.ac.uk/ws/portalfiles/portal/4755978/ Julius+Ojebode\%27s+Thesis.pdf\%0Ausir. salford.ac.uk/29369/1/Angela_Darvill_thesis esubmission.pdf\%0Ahttps://dspace.lboro.ac.uk/ dspace-jspui/ha

21. Prayogo AHE. Faktor-Faktor Yang Mempengaruhi Kepatuhan Minum Obat Anti Tuberculosis Pada Pasien Paru [Internet]. Vol. 84. Universitas Iskam Negeri Syarif Hidayatullah; 2013. Tersedia pada: http://ir.obihiro.ac.jp/dspace/handle/10322/3933

22. Sumiahadi A, Acar R, Odoh CK, Martins PE, Akpi UK, Okekeaji U, et al. karakteristik penderita tuberkulosis. Chemosphere [Internet]. 2017; 7(1):13-9. Tersedia pada: http://dx.doi.org/10.1016/ bs.ampbs.2017.04.001\%0Ahttp://dx.doi. org/10.1016/j.arabjc.2013.08.010\%0Ahttp:// dx.doi.org/10.1016/j.chemosphere.2013.01.0 75\%0Ahttp://www.pnas.org/cgi/doi/10.1073/ pnas.0308555101\%0Ahttp://www.treemediation. com/technical/phytoremed 